\title{
PKM Layanan Sistem Informasi Barcode Berbasis Website untuk Perpustakaan Desa Binor
}

Bambang ${ }^{1}$, Fanny Brawijaya², Muhammad Rofiqi ${ }^{3}$, M. Kifliyanto ${ }^{4}$, M. Luqman Hakim ${ }^{5}$, Mohammad Ali Makki ${ }^{6}$, Luthfi Fu'ady ${ }^{7}$, Mirza Alief Nurzahwa ${ }^{8}$

Universitas Nurul Jadid, Paiton ${ }^{123}$

\begin{tabular}{ll}
\hline Submission: 11/09/2021 Received: 31/12/2021 Published: 31/12/2021 \\
\hline $\begin{array}{l}\text { Keywords: } \\
\text { Library, }\end{array}$ & Abstract. The Binur Village Library is used by visitors as a medium \\
information & to find references and places to learn. The problem faced by the \\
system, & Binur Village library is that it does not have a web-based library \\
Web, & analyze, design, and implement a web-based library information \\
Codelgneter & system, as well as testing. The system development method uses \\
& analysis and design using Flowcharts, implemented with the \\
& Codelgniter programming language and MySQL as data storage. \\
& The result of the research is a library information system that can \\
& collect data on members, serve borrowing and return book \\
transactions directly, search for books, make reports on borrowing \\
books and register members at the Binur Village library.
\end{tabular}

Katakunci: $\quad$ Abstrak. Perpustakaan Desa Binur difungsikan pengunjung sebagai Perpustakaan, media untuk mencari referensi dan tempat belajar. Permasalahan Sistem informasi, yang dihadapi perpustakaan Desa Binur adalah tidak mempunyai Web, Codelgneter Sistem Informasi perpustakaan berbasis web untuk melayani kebutuhan pengguna. Penelitian ini bertujuan untuk menganalisis, merancang, dan mengimplementasi sebuah sistem informasi perpustakaan berbasis web, serta dilakukan pengujian. Metode pengembangan sistem menggunakan analisis dan perancangan menggunakan Flowchart, diimpelementasikan dengan bahasa pemrograman Codelgniter dan MySQL sebagai tempat penyimpanan data. Hasil penelitian adalah sebuah system informasi perpustakaan yang dapat melakukan pendataan anggota, melayani transaksi peminjaman dan pengembalian buku secara langsung, pencarian buku, membuat laporan peminjaman buku serta mendata anggota pada perpustakaan Desa Binur.

\section{Pendahuluan}

Pada zaman era sekarang ini perkembangan teknologi berkembang pesat, dengan adanya teknologi meningkatkan kualitas dari kerja yang mau dilakukan, adapun adanya pada suatu sistem informasi yang akurat dalam penyajian informasinya.

Untuk meningkatkan pengetahuan yang peran pada perpustakaan sangat penting dalam kebutuhannya, ditengah siswa oleh karena itu perpustakaan 
dapat meningkatkan ilmu pengetahuan kepada siswanya. Dalam pelayanan luas maka dari itu dapat memanfaatkan teknologi informasi dapat membantu memenuhi kebutuhan siswa maupun segi pelayanan perpustakaan desa, sehingga dalam pengolahan datanya dapat dilakukan dengan cara cepat dan akurat. Saat ini adanya fasilitas di Perpustakaan Desa Binur mengalami kemajuan: ruang perpustakaan. Adapun aktifitas kegiatan yang dilakukan seperti pada perpustakaan yaitu pengolahan data, peminjaman, ataupun pengembalian, dan juga denda pengembalian buku. Dalam proses pengolahan data perpustakaan desa Binur dilakukan secara manual atau konvensional yaitu proses catatan data buku, anggota, data peminjaman, data pengembalian dan denda masih dilakukan buku nota biasa. Untuk proses berjalandi perpustakaan yaitu setiap siswa di sekolah perpustakaan desa.

Binur yang akan meminjam buku ke perpustakaan terus dicatat oleh petugas perpustakaan dimana dalam sekali meminjam diberi satu minggu. Maka jika dari siswa yang meminjam buku terlambat dalam pengembalian akan dikenakan denda dari setiap buku. Sistem informasi barcode perpustakaan desa berbasis web menggunakan suatu bahasa pemrograman dengan menggunakan alat barcode, dapat mempermudah petugas dalam mengelola data peminjaman buku dan pengembalian buku perpustakaan, untuk proses pencarian buku, pengolahan data anggota akan cepat efektif dan efisien.

Beberapa penelitian Penelitian pertama oleh jurnal (speed) Fakultas Teknologi Informatika Universitas Surakarta (UNSA) volume 9 Nomor 2 Agustus 2012 dimuat naskah dengan judul "Pembangunan Sistem Informasi Perpustakaan Pada Sekolah Menengah Pertama Negeri 4 Karang Tengah"yang ditulis oleh Sulastri, Bambang Eka Purnama, Sukadi, diuraikan bahwa Perpustakaan adalah infrastruktur yang sangat vital bagi suatu institusi atau bagi lembaga pendidikan, perpustakaan didirikan untuk memenuhi kebutuhan informasi masyarakat, khususnya untuk masyarakat dari ekonomi lemah. Selama ini pelayanan yang diberikan oleh perpustakaan Sekolah Menengah Pertama (SMP) Negeri 4 Karangtengah masih menggunakan cara - cara yang konvensional dan bisa menghambat proses transaksi peminjaman di perpustakaan tersebut. Dengan adanya hal ini maka untuk mengatasinya dibuatlah suatu perangkat lunak yang bisa membantu petugas perpustakaan dalam hal proses peminjaman serta pengelolaan data buku perpustakaan 
Sekolah Menengah Pertama (SMP) Negeri 4 Karangtengah. Sistem ini nantinya diharapkan dapat menghasilkan kemudahan dalam pengelolaan di perpustakaan, sehingga perkembangan dalam proses pengolahan data-data buku akan berlangsung dengan cepat.

Penelitian kedua oleh Pada jurnal (speed) Fakultas Teknologi Informatika Universitas Surakarta (UNSA) volume 2 Nomor 2 Agustus 2012 dimuat naskah dengan judul "Pembuatan Sistem Informasi Perpustakaan Pada SMP Muhammadiyah 7 Surakarta" yang ditulis oleh Arip Aryanto, Berliana Kusuma Riasti ST.M.Eng diuraikan bahwa sistem Informasi Perpustakaan di SMP Muhammadiyah 7 Surakarta masih menggunakan cara manual yaitu pencatatan peminjaman, pengembalian, data koleksi, data anggota dan denda, sehingga membutuhkan waktu yang lama untuk mendapatkan informasi yang diinginkan. Oleh karena itu dibutuhkan sistem informasi perpustakaan yang memadai untuk memproses pendataan anggota, data koleksi, proses peminjaman, pengembalian, denda, dan menghasilkan informasi yang cepat dan tepat. Dengan memanfaatkan "Sistem Informasi Perpustakaan di SMP Muhammadiyah 7 Surakarta" ini maka tingkat pelayanan kepada siswa menjadi lebih baik dari sebelumnya. Dalam penelitian ini akan di kemukakan bagaimana sistem informasi barcode perpustakaan desa Binur berbasis web beserta penerapannya.

\section{Metode}

Pada aplikasi sistem informasi perpustakaan desa membutuhkan caranya ataupun sebuah metode untuk menghasilkan sebuah aplikasi yang bisa bermanfaat bagi masyarakat.

Adapun metode penelitian digunakan dalam penelitian menggunakan metode kualitatif. Dengan metode kualitatif ini bisa dalam pengumpulan data yang digunakan dihasilkan dengan wawancara dan observasi. 
Tahapan kerangkapemikiran dapat dilihat pada Gambar 1

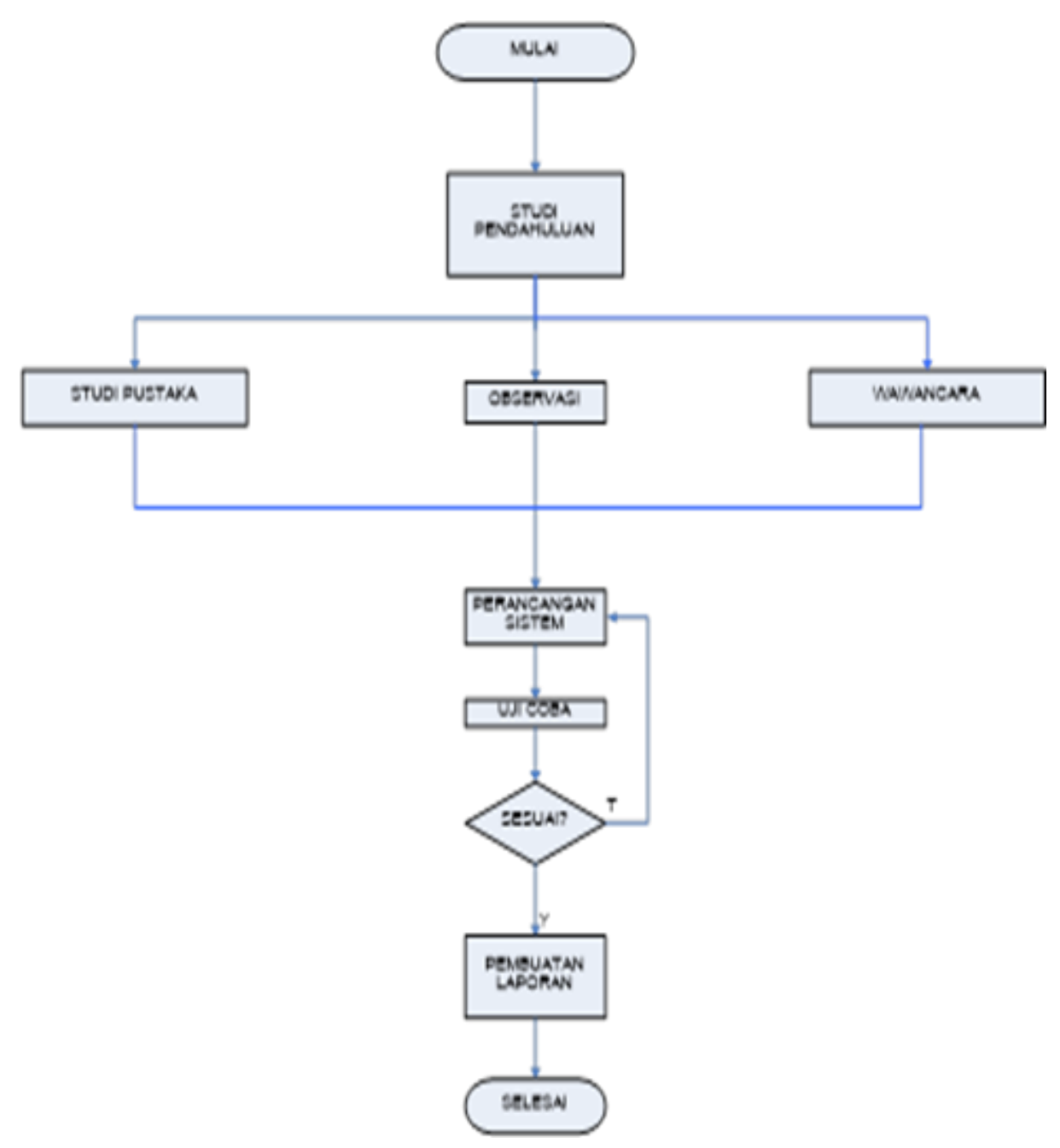

Model pengembangan yang digunakan dalam penelitian ini adalah model pengembangan waterfall. Model Waterfall ialah suatu proses pengembangan perangkat lunak berurutan, di mana kemajuan dipandang sebagai terus mengalir ke bawah (seperti air terjun) melewati fase-fase perancangan, permodelan, implementasi (konstruksi), dan pengujan. Dalam pengembangan waterfall memiliki beberapa tahapan runtut: requerement (analisis kebutuhan), design sistem (system design), coding \& testing penerapan program pemeliharaan (Tristinto, 2018). 


\section{Model Pengembangan}

Dalam langkah - langkah penelitian model pengembangan waterfall pada gambar 2 tersebut, akan dijelaskan lebih terperinci, yaitu sebagai berikut:

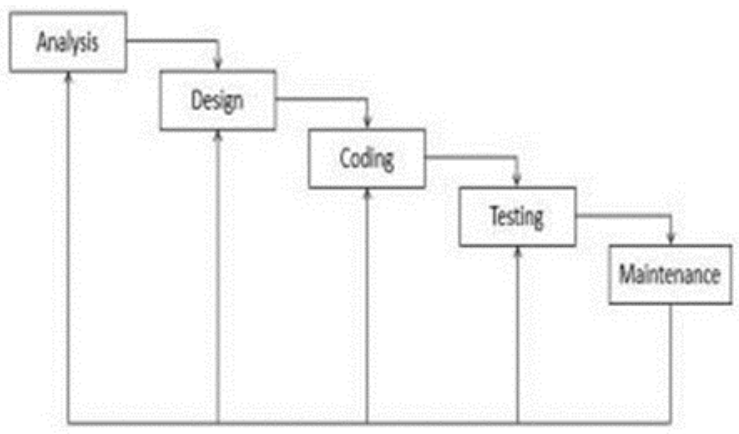

\section{Requirement (Analisis Kebutuhan)}

\section{Observasi}

Observasi di lakukan di Kantor Desa Binur untuk mendapatkan informasi yang mengenai proses penyampaian perpustakaan desa selama ini berjalan. Observasi untuk mengumpulan data berkaitan dengan perpustakaan desa di Kantor Desa Binur untuk melihat objek yang diteliti. Penelitian mendapatkan berapa data di lakukan seperti pengolahan data, peminjaman, ataupun juga denda pengembalian buku.

\section{Wawancara}

Wawancara dilakukan di Kantor Desa Binur dengan saudara Hasan Basri, S.Pd.I selaku kepala desa di Kantor Desa Binur untuk mendapatkan kebutuhan pengguna secara langsung dengan bertanya .

\section{Studi Literatur}

Pada ditahap ini bertujuan untuk mengenali dan mendapatkan informasi dari suatu konsep penerapan terhadap sistem yang dibuat. Studi pustaka juga dilakukan untuk mendapatkan referensi teori-teori terkait terhadap kasus/permasalahan yang ada. Referensi ini bisa didapat pada sebuah jurnal, artikel, buku, beberapa situs di internet. 


\section{Design System (Desain Sistem)}

Pada tahap desain ini merancang sistem yang akan dibuat menggunakan beberapa bagian yang akan dijajadikan acuan programmer dalam membuat sistem. Bagian - bagian tersebut terdiri atas Flowchart Sistem, DFD (Data Flow Diagram), ERD (Entity Relationship Diagram) serta membuat desain Form aplikasiyang akan digunakan.

\section{Coding \& Testing (Penulisan Sinkode Program / Implemention)}

Pada tahap ini merupakan implementasi kasus/permasalahan ke sebuah bahasa pemerograman yang kita kenal dengan istilah koding. Pada tahap ini web editor yang digunakan Microsoft Visual Code dan bahasa pemrograman PHP.

\section{Penerapan / Pengujian Program (Integration \& Testing).}

Pengujian sistem yang akan dilakukan dalam aplikasi ini yaitu dengan melakukan pengujian secara internal (blackbox testing testing) dan pengujian secara eksternal (user).

\section{Pemeliharaan (Operation \& Maintenance)}

Setelah itu tahap penerapan atau pengujian program selesai, untuk tahap selanjutnya melakukan perawatan pada perangkat lunak yang dibuat yaitu sistem informasi barcode perpusdes Binur berbasis web dirancang menggunakan bahasa pemrograman web PHP. Perawatan ini dilakukan seorang administrator dimana bisa meningkatkan kualitas aplikasi tersebut sangat lebih baik. 


\section{Hasil dan Pembahasan}

\section{Rekayasa Kebutuhan (Requirement)}

Rekayasa kebutuhan dapat dibagi menjadi 2 bagian. Yaitu kebutuhan fungsional dan kebutuhan Non- fungsional: 1) Kebutuhan fungsional Petugas dapat menginput, data anggota, data buku, transaksi peminjaman; 2) Anggota dapat melihat data peminjaman dan pengembalian; 3) Kepala Perpusdes dapat melihat laporan peminjaman dan pengembalian

\section{Kebutuhan Non-fungsional}

Di antaranya adalah 1) Perangkat Keras: (Hardware), Personal Computer (PC)/ Laptop, Processor minimal intel (R) Core i3, Ram minimal 2048 MB, Hardisk 250GB, Printer; 2) Perangkat Lunak (software): Sistem Operasi Windows 8, Xampp Control Panel V3.2.2, Microsoft visio 2007, PowerDesaigner6, MySQL, Google Chrome.

\section{Hasil Observasi dan Wawancara}

Dari hasil observasi dan wawancara berdasarkan data yang diperoleh yang dilampirkan dihasil wawancara maka sangat membutuhkan sebuah sistem perpurdes, maka pada analisis data penelitian akan menjabarkan langkahlangkah model Waterfall di mulai dari rekayasa kebutuhan, desain, implementasi.

\section{Desain Sistem}

Adapun tahapan dalam proses pelaksanaan penelitian ini, agar terhindar dari kesalahan yang mungkin terjadi dalam perancangan dan pembangunan Sistem Informasi Barcode Perpustakaan Desa Binur Berbasis Web 


\section{Desain Flowchart}

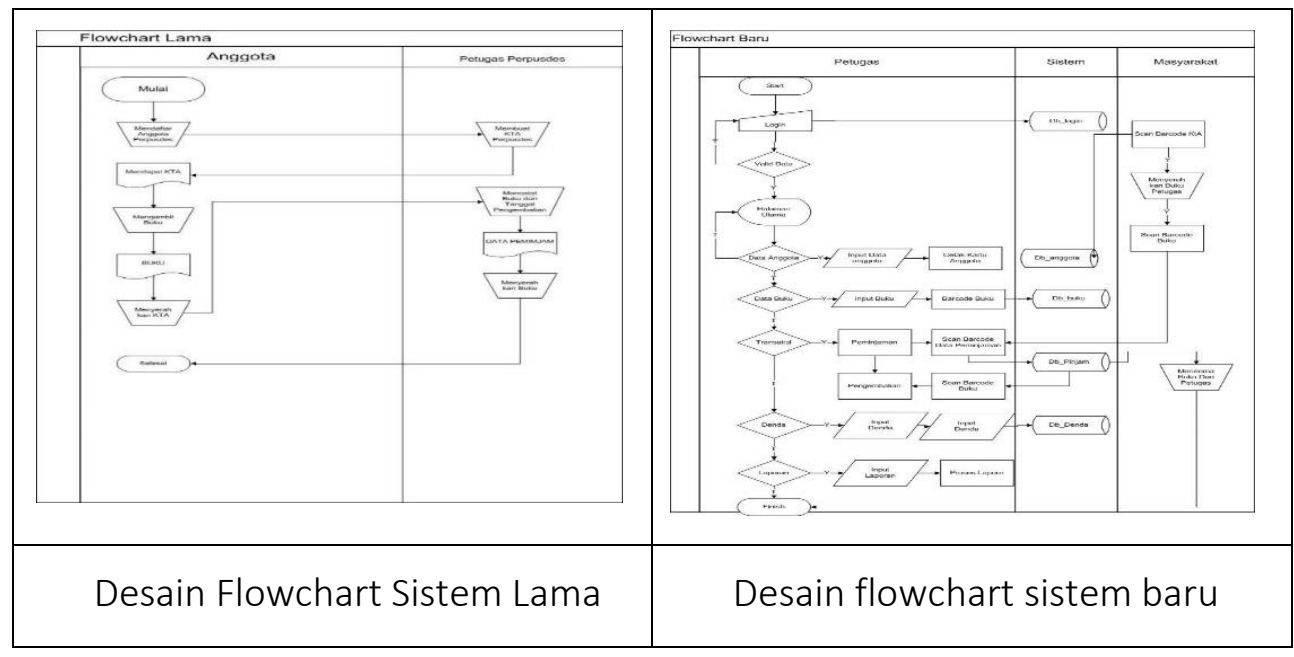

Diagram Alur Data (Data Flow Diagram)

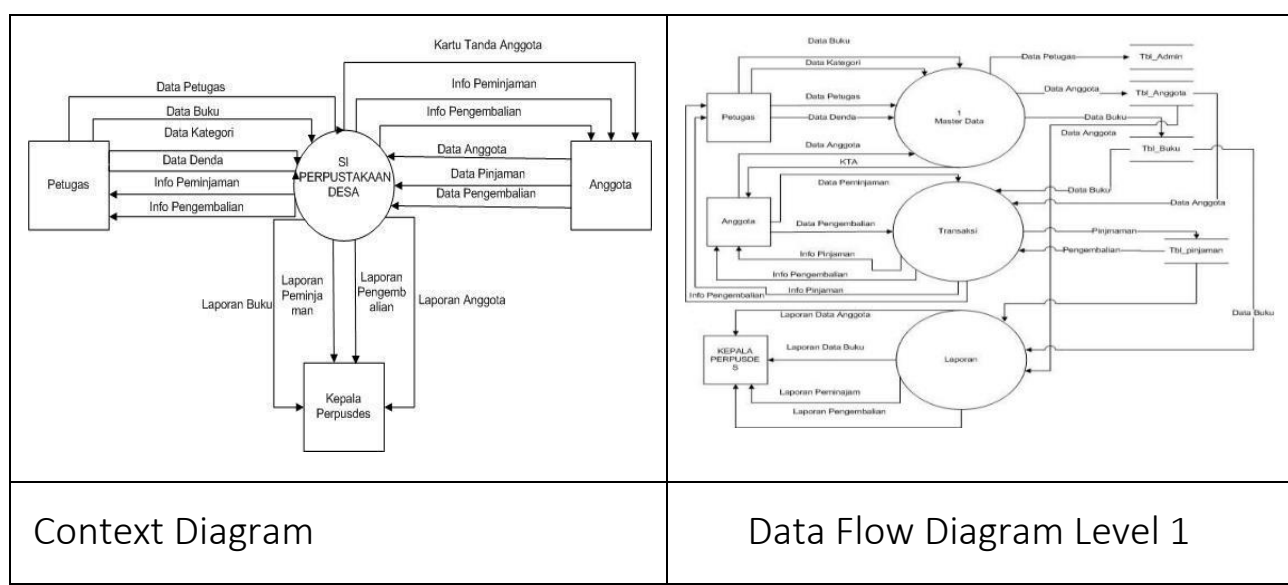




\section{Entity Relationship Diagram (ER-D)}

Gambar Entity Relationship Diagram (ER-D)

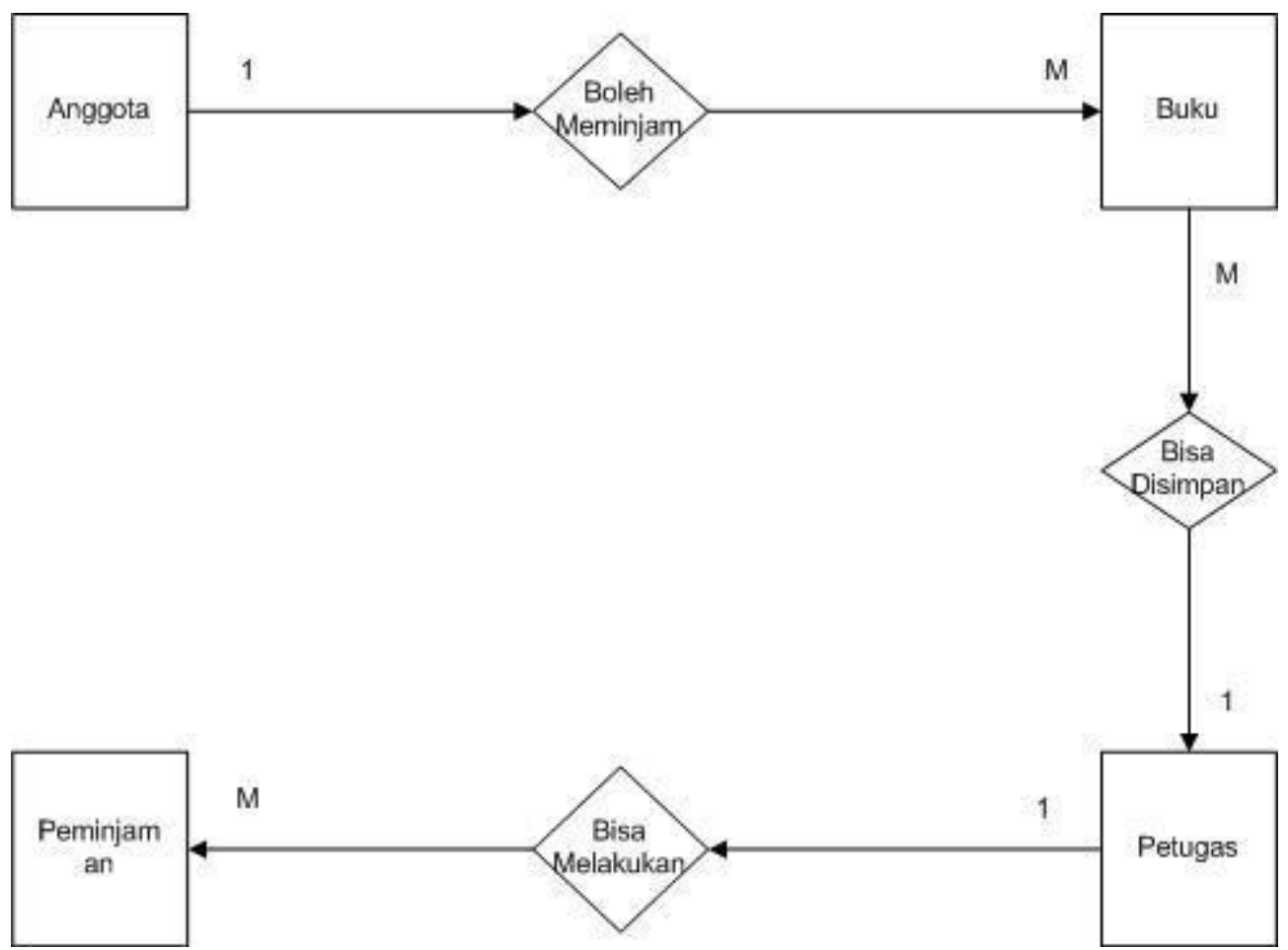

\section{Desain Database}

Database log-in

\begin{tabular}{|l|l|l|l|l|l|}
\hline \multicolumn{1}{|c|}{ Name } & \multicolumn{1}{|c|}{ Type } & \multicolumn{1}{c|}{ Collation } & \multicolumn{1}{c|}{ Attribute } & \multicolumn{1}{c|}{ Null } & \multicolumn{1}{c|}{ Default } \\
\hline Id login & int(11) & utf8mb4_ge neral_ci & AUTO_IN CREMENT & No & None \\
\hline Barcode_Anggota & $\operatorname{varchar(100)}$ & utf8mb4_ge neral_ci & & No & None \\
\hline User & $\operatorname{varchar(255)}$ & utf8mb4_ge neral_ci & & No & None \\
\hline Pass & $\operatorname{varchar(255)}$ & utf8mb4_ge neral_ci & & No & None \\
\hline Level & $\operatorname{varchar(255)}$ & utf8mb4_ge neral_ci & & No & None \\
\hline Nama & $\operatorname{varchar(255)}$ & utf8mb4_ge neral_ci & & No & None \\
\hline Tempat_lahir & $\operatorname{varchar(255)}$ & utf8mb4_ge neral_ci & & No & None \\
\hline Tgl_lahir & $\operatorname{varchar(255)}$ & utf8mb4_ge neral_ci & & No & None \\
\hline Jengkel & $\operatorname{varchar}(255)$ & utf8mb4_ge neral_ci & & No & None \\
\hline Alamat & Text & utf8mb4_ge neral_ci & & No & None \\
\hline Telephone & $\operatorname{varchar(255)}$ & utf8mb4_ge neral_ci & & No & None \\
\hline Email & $\operatorname{varchar(255)}$ & utf8mb4_ge neral_ci & & No & None \\
\hline Foto & $\operatorname{varchar}(255)$ & utf8mb4_ge neral_ci & & No & None \\
\hline
\end{tabular}




\section{Database buku}

\begin{tabular}{|l|l|l|l|l|c|}
\hline \multicolumn{1}{|c|}{ Name } & \multicolumn{1}{c|}{ Type } & \multicolumn{1}{c|}{ Collation } & Attribute & Null & Default \\
\hline Id_buku & int(11) & utf8mb4_general_ci & AUTO_INCREMENT & No & None \\
\hline buku_id & varchar(255) & utf8mb4_general_ci & & No & None \\
\hline Barcode_buku & $\operatorname{varchar(100)}$ & utf8mb4_general_ci & & No & None \\
\hline Id_kategoeri & int(11) & utf8mb4_general_ci & & No & None \\
\hline Id_Rak & int(11) & utf8mb4_general_ci & & No & None \\
\hline Sampul & varchar(255) & utf8mb4_general_ci & & No & None \\
\hline Isbn & $\operatorname{varchar(255)}$ & utf8mb4_general_ci & & No & None \\
\hline Iampiran & $\operatorname{varchar(255)}$ & utf8mb4_general_ci & & No & None \\
\hline Title & $\operatorname{varchar(255)}$ & utf8mb4_general_ci & & No & None \\
\hline Penerbit & $\operatorname{varchar(255)}$ & utf8mb4_general_ci & & No & None \\
\hline Pengarang & $\operatorname{varchar(255)}$ & utf8mb4_general_ci & & No & None \\
\hline Thn_buku & $\operatorname{varchar(255)}$ & utf8mb4_general_ci & & No & None \\
\hline Jml & int(11) & utf8mb4_general_ci & & No & None \\
\hline Isi & Text & utf8mb4_general_ci & & No & None \\
\hline
\end{tabular}

\section{Database Pinjam}

\begin{tabular}{|l|l|l|l|l|l|}
\hline \multicolumn{1}{|c|}{ Name } & \multicolumn{1}{c|}{ Type } & \multicolumn{1}{c|}{ Collation } & Attribute & Null & \multicolumn{1}{c|}{ Default } \\
\hline Id_pinjam & int(11) & utf8mb4_general_ci & AUTO_INCREMENT & No & None \\
\hline Pinjam_id & varchar(255) & utf8mb4_general_ci & & No & None \\
\hline Anggota_id & varchar(100) & utf8mb4_general_ci & & No & None \\
\hline Buku_id & int(11) & utf8mb4_general_ci & & No & None \\
\hline Status & int(11) & utf8mb4_general_ci & & No & None \\
\hline Tgl_pinjam & varchar(255) & utf8mb4_general_ci & & No & None \\
\hline Lama_pinjam & int(11) & utf8mb4_general_ci & & No & None \\
\hline Tgl_balik & varchar(255) & utf8mb4_general_ci & & No & None \\
\hline Tgl_kembali & varchar(255) & utf8mb4_general_ci & & No & None \\
\hline
\end{tabular}

\section{Database Kategori}

\begin{tabular}{|c|l|l|l|c|c|}
\hline \multicolumn{1}{|c|}{ Name } & \multicolumn{1}{|c|}{ Type } & \multicolumn{1}{c|}{ Collation } & Attribute & Null & Default \\
\hline Id Katego ri & int(11) & utf8mb4_general_ci & AUTO_IN CREMENT & No & None \\
\hline Nama_kategori & $\operatorname{varchar(255)}$ & utf8mb4_general_ci & & No & None \\
\hline
\end{tabular}

\section{Database Denda}

\begin{tabular}{|l|l|l|l|c|c|}
\hline Name & Type & Collation & Attribute & Null & Default \\
\hline Id_denda & int(11) & utf8mb4_general_ci & AUTO_IN CREMENT & No & None \\
\hline Pinjam_id & $\operatorname{varchar(255)}$ & utf8mb4_general_ci & & No & None \\
\hline Denda & $\operatorname{varchar(255)}$ & utf8mb4_general_ci & & No & None \\
\hline Lama_waktu & int(11) & utf8mb4_general_ci & & No & None \\
\hline Tgl_dendaa & $\operatorname{varchar(255)}$ & utf8mb4_general_ci & & No & None \\
\hline
\end{tabular}




\section{Desain Interface}

\section{Desain Input Output}

Halaman login

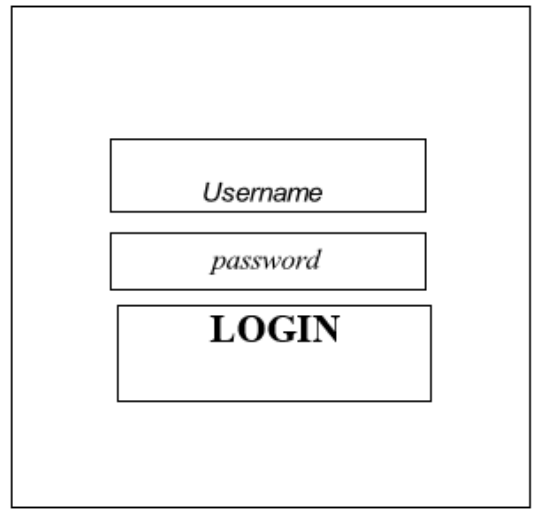

Tampilan Halaman Utama

\begin{tabular}{|l|c|c|c|}
\hline \multicolumn{3}{|c|}{ HALAMAN UTAMA } \\
\hline LOGO & \multicolumn{3}{|c|}{} \\
\cline { 1 - 2 } Pengguna & $\begin{array}{c}\text { JUMLAH } \\
\text { Anggota }\end{array}$ & $\begin{array}{c}\text { JUMLAH } \\
\text { Buku }\end{array}$ & $\begin{array}{c}\text { PUMLAH } \\
\text { Buku }\end{array}$ \\
\cline { 1 - 2 } Transaksi & \multicolumn{3}{|c|}{} \\
\cline { 1 - 2 } Denda & \multicolumn{3}{|c|}{} \\
\hline
\end{tabular}

Tampilan Input Buku

\begin{tabular}{|l|l|l|}
\hline Input Buku & \multicolumn{2}{|l|}{} \\
\hline Barcode: ...... & Tahun Terbit : .... \\
\hline \multirow{3}{*}{$\begin{array}{l}\text { Kategori : Pilih } \\
\text { Kategori }\end{array}$} & Jumlah Buku : .... \\
\hline Rak : Pilih Rak Buku & Ex : Rak Buku 1, Rak Buku 2 dst & Foto : .... \\
\hline Judul Buku : & & Ket $: \ldots$. \\
\hline Nama Pengarang : & & \\
\hline Nama Penerbit : & & \\
\hline
\end{tabular}

\section{Tampilan Transaksi}

\begin{tabular}{|c|c|c|}
\hline Data Transaksi & \multirow{2}{*}{\multicolumn{2}{|c|}{\begin{tabular}{|l} 
Data Buku \\
Kode_Buku :
\end{tabular}}} \\
\hline No. Peminjaman : ......... & & \\
\hline Tgl_Peminjaman : ......... & Data Buku : & \\
\hline \multicolumn{2}{|l|}{ Id Anggota : ............... } & \\
\hline \multicolumn{3}{|l|}{ Biodata Anggota : ........ } \\
\hline Lama Peminjaman : ....... & & \\
\hline & Simpan & Kembali \\
\hline
\end{tabular}


Implementasi

Halaman Log-in

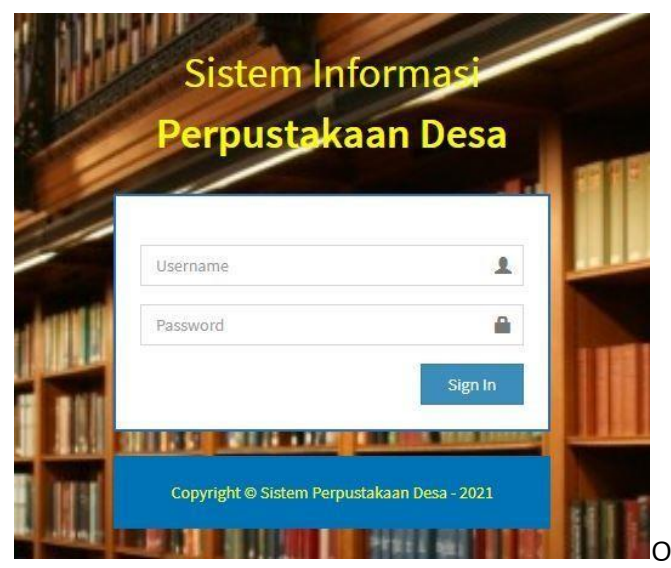

Halaman Pengguna/ Anggota

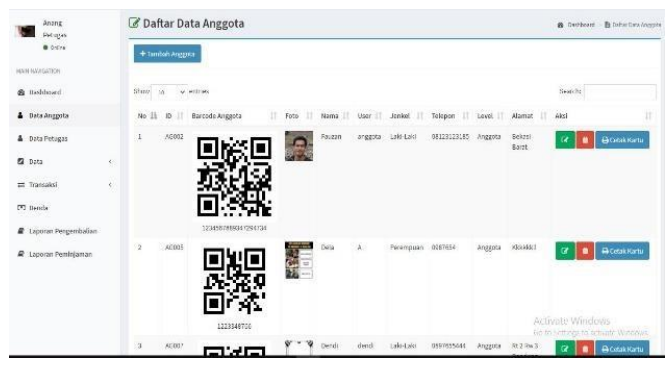

Halaman Tambah

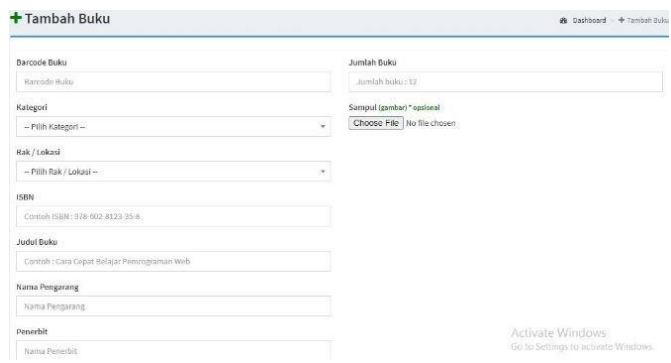

Halaman Menu Utama

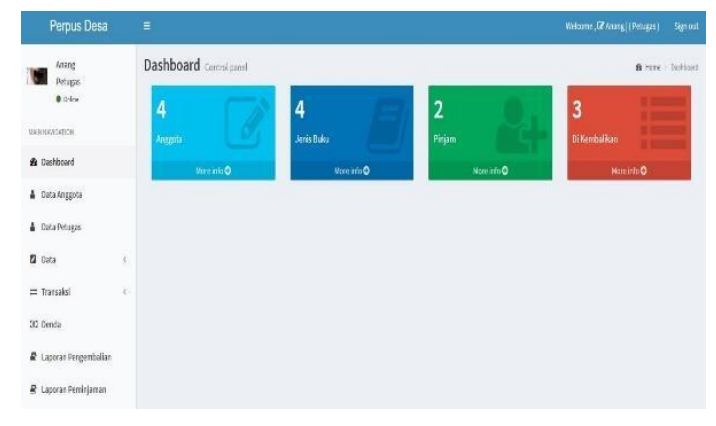

Halaman Data Buku

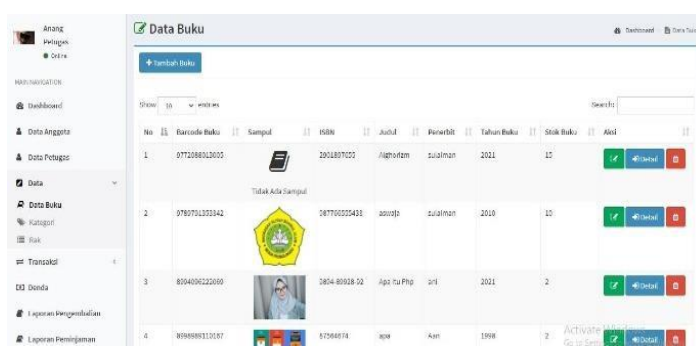

Halaman Transaksi Pinjaman

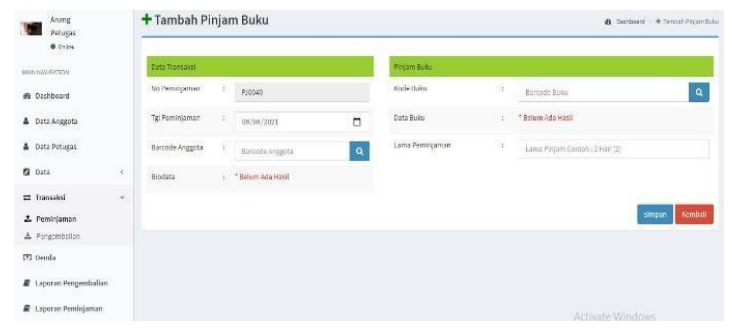


Halaman Transaksi Pengembalian

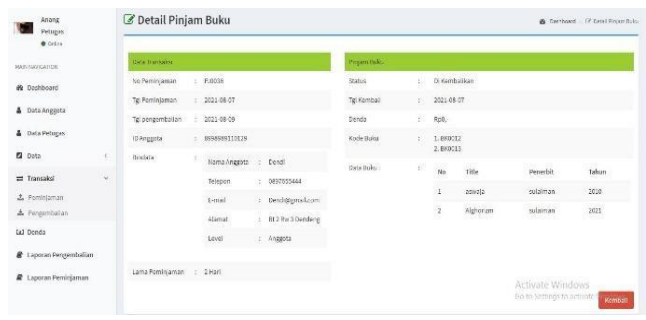

Halaman Data Pengembalian

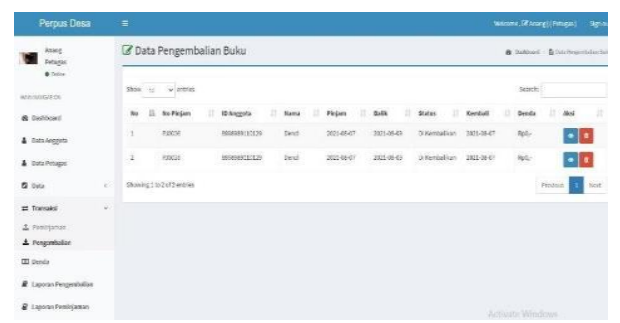

\section{Halaman Denda}

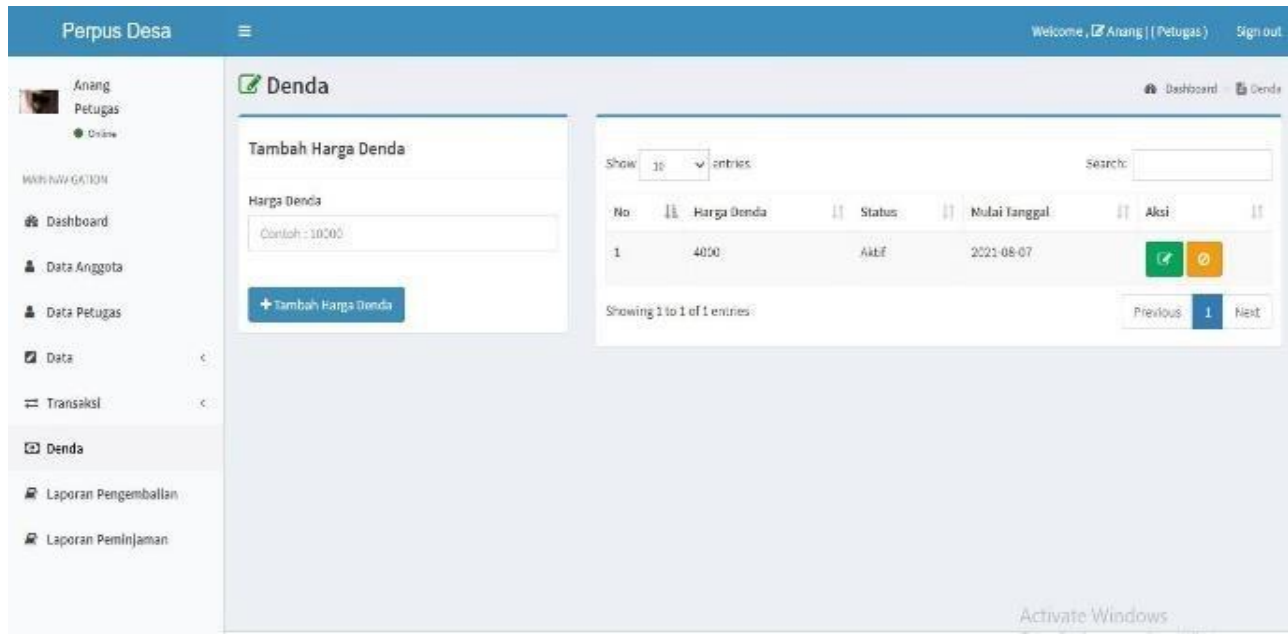

\section{Revisi Produk}

Dari hasil observasi dan wawancara berdasarkan data yang diperoleh, maka pada analisis data penelitian akan menjabarkan langkah-langkah model Waterfall di mulai dari pengujian dan pemeliharaan.

\section{Pengujian}

Pengujian aplikasi diagnosa dilakukan untuk mengetahui implementasi kesesuaian dengan perancangan yang dilakukan sebelumnya. Adapun pengujian sistem yang dilakukan yaitu dengan melakukan pengujian internal (Black Box Testing) dan pengujian eksternal (Kuesioner). 


\section{Pengujian Internal (blackbox testing)}

Pengunjian internal dilakukan dengan cara menguji program langsung kepada seorang pakar, adapun pakar yang menguji langsung sistem ini adalah Bapak Bambang, M.Kom dosen di Universitas Nurul Jadid.

Tabel 1. Hasil Pengujian Internal Oleh Pakar

\begin{tabular}{|c|c|c|c|c|c|}
\hline \multirow{2}{*}{ NO } & \multirow{2}{*}{ Form } & \multirow{2}{*}{$\begin{array}{l}\text { Target yang } \\
\text { ingin dicapai }\end{array}$} & \multirow{2}{*}{ Hasil yang diinginkan } & \multicolumn{2}{|c|}{ Kesesuaian } \\
\hline & & & & Sesuai & Tidak \\
\hline 1 & Form login & $\begin{array}{l}\text { Berhasil untuk } \\
\text { melakukan ogin }\end{array}$ & $\begin{array}{l}\text { Petugas bisa login } \\
\text { untuk masuk atau } \\
\text { memulai system } \\
\text { informasi perpusdes }\end{array}$ & $\checkmark$ & \\
\hline 2 & $\begin{array}{l}\text { Menu utama / } \\
\text { dashboard }\end{array}$ & $\begin{array}{l}\text { Menampilkan } \\
\text { halaman utama } \\
\text { aplikasi }\end{array}$ & $\begin{array}{l}\text { Menampilkan menu } \\
\text { utama petugas telah } \\
\text { memasuki sistem }\end{array}$ & $\checkmark$ & \\
\hline 3 & $\begin{array}{l}\text { Menu daftar } \\
\text { anggota }\end{array}$ & $\begin{array}{l}\text { Mengelola data } \\
\text { anggota }\end{array}$ & $\begin{array}{l}\text { Berhasil melakukan } \\
\text { tambah/edit/hapus } \\
\text { pada data anggota }\end{array}$ & $\checkmark$ & \\
\hline 4 & $\begin{array}{l}\text { Menu daftar } \\
\text { buku }\end{array}$ & $\begin{array}{l}\text { Mengelola data } \\
\text { buku }\end{array}$ & $\begin{array}{l}\text { Berhasil melakukan } \\
\text { tambah/edit/hapus } \\
\text { pada data buku }\end{array}$ & $\checkmark$ & \\
\hline 5 & $\begin{array}{l}\text { Menu daftar } \\
\text { peminjam }\end{array}$ & $\begin{array}{l}\text { Mengelola data } \\
\text { peminjaman buku }\end{array}$ & $\begin{array}{l}\text { Berhasil melakukan } \\
\text { tambah/edit/hapus } \\
\text { pada data } \\
\text { peminjaman buku }\end{array}$ & $\checkmark$ & \\
\hline 6 & $\begin{array}{l}\text { Menu daftar } \\
\text { pengemb alian } \\
\text { buku }\end{array}$ & $\begin{array}{l}\text { Mengelola data } \\
\text { pengembalian } \\
\text { buku }\end{array}$ & $\begin{array}{l}\text { Berhasil melakukan } \\
\text { tambah/edit/hapus } \\
\text { pada data } \\
\text { pengembalian buku }\end{array}$ & $\checkmark$ & \\
\hline 7 & Menu logout & $\begin{array}{l}\text { Berhasil } \\
\text { mengakhiri sistem }\end{array}$ & $\begin{array}{l}\text { Berhasil mengakhiri } \\
\text { sistem dan kembali ke } \\
\text { halaman login }\end{array}$ & $\checkmark$ & \\
\hline
\end{tabular}

\section{Pengujian Eksternal}

Pengujian Eksternal dilakukan dengan cara menguji menggunakan kuesioner kepada pihak bersangkutan yaitu Kepala Desa dan perangkat desa Binur. Adapun hasil perhitungan skala likert pengujian Sistem Perpusdes yang terdiri dari 9 Perangkat dan 1 Kepala Desa Binur didapatkan data sebagai berikut: 
Tabel 2

\begin{tabular}{|l|l|c|c|c|c|}
\hline \multirow{2}{*}{ No. } & \multirow{2}{*}{ Target ingin dicapai } & \multicolumn{4}{|c|}{ Kesesuaian } \\
\cline { 3 - 5 } & & Sangat & \multirow{2}{*}{ Setuju } & Kurang & Tidak \\
\cline { 5 - 6 } & & Setuju & Setuju & Setuju \\
\hline 1 & $\begin{array}{l}\text { Apakah aplikasi sistem } \\
\text { informasi dapat berjalan } \\
\text { dengan baik? }\end{array}$ & 5 & 5 & 0 & 0 \\
\hline 2 & $\begin{array}{l}\text { Apakah aplikasi sistem } \\
\text { informasi dapat membantu } \\
\text { peminjaman buku di } \\
\text { perpustakaan desa? }\end{array}$ & 6 & 4 & 0 & 0 \\
\hline 3 & $\begin{array}{l}\text { Apakah menu yang ada } \\
\text { sudah cukup }\end{array}$ & 1 & 4 & 5 & 0 \\
\hline 4 & $\begin{array}{l}\text { Apakah tampilan atau } \\
\text { desain aplikasi sudah } \\
\text { menarik? }\end{array}$ & 1 & 8 & 1 & 0 \\
\hline 5 & $\begin{array}{l}\text { Apakah aplikasibisa di } \\
\text { oprasikan denganmudah } \\
\text { oleh user? }\end{array}$ & 4 & 6 & 0 & 0 \\
\hline & Total & 17 & 27 & 6 & 0 \\
\hline
\end{tabular}

Hasil Pengujian Eksternal

Tabel 3 Bobot Nilai

\begin{tabular}{|c|c|}
\hline$A$ & 4 \\
\hline$B$ & 3 \\
\hline$C$ & 2 \\
\hline$D$ & 1 \\
\hline
\end{tabular}

\begin{tabular}{|c|c|}
\hline Jawaban & Keterangan \\
\hline $0 \%-24,99 \%$ & Kurang \\
\hline $25 \%-49,99 \%$ & Cukup \\
\hline
\end{tabular}




\begin{tabular}{|c|c|}
\hline $50 \%-74,99 \%$ & Baik \\
\hline $75 \%-100 \%$ & Sangat Baik \\
\hline
\end{tabular}

Tabel 4 Presentase Nilai

Dari data yang sudah didapat diatas kemudian dikalikan setiap point dengan bobot yang sudah ditentukan dengan tabel bobot nilai. Adapun hasil perhitungan jawaban responden sebagai berikut:

Perolehan Skor

$$
\begin{aligned}
& \mathrm{SS}=4 \times 17=68 \\
& \mathrm{~S}=3 \times 81=81 \\
& \mathrm{KS}=2 \times 6=12 \\
& \mathrm{TS}=1 \times 0=0
\end{aligned}
$$

Skor Hasil Pengumpulan Data

$$
\begin{aligned}
\text { SKP } & =68+81+12+0 \\
& =161
\end{aligned}
$$

Skor ldeal

$$
\begin{aligned}
\text { Skor } & =4 \times 5 \times 10 \\
\text { Ideal } & \\
& =200
\end{aligned}
$$


Nilai Akhir

$$
\begin{aligned}
P= & 161 \\
& () \times 100 \% \\
& 200 \\
= & 80,5 \%
\end{aligned}
$$

Berdasarkan rating scale menggunakan skala interpretasi likert dapat disimpulkan bahwa Sistem Informasi Barcode Perpustakaan Desa Binur berbasis Web layak digunakan dan sangat baik untuk digunakan dengan perhitungan pengujian sebesar $80,5 \%$.

\section{Kesimpulan}

Dari penelitian yang telah dilakukan, maka di simpulkan :

1. Penelitian ini berhasil merancang dan membangun sistem informasi barcode pepustakaan desa Binur berbasis web.

2. Sistem informasi barcode pepustakaan desa Binur berbasis web ini untuk memudahkan petugas perpusdes dalam melayani masyarakat dalam pendataan buku dan peminjaman serta pengembalian buku.

3. Sistem informasi barcode pepustakaan desa Binur berbasis web ini dapat membuat laporan secara berkala yang dapat diajukan ke Kepala Perpusdes.

4. Hasil pengujian berdasarkan hasil angket kepada 10 responden masyarakat Binur yang menyatakan 80,5 \% (sangat baik) sehingga Sistem informasi barcode perpusdes ini layak digunakan.

\section{Daftar Pustaka}

Adi Prawira, Y. B. (2018). Perancangan Sistem Informasi Perpustakaan Di SMKN 01 Kedung Waru Tulungangung. Genertion Jurnal/Vol. 2 NO 2 eISSN : 2549 - 2233 / p-ISSN :2580-4952, 73 - 82. 
Deanna Durbin Hutagalung1, F. A. (2018). RANCANG BANGUN SISTEM INFORMASI PERPUSTAKAAN BERBASIS WEB PADA SMK CITRA NEGARA DEPOK. Jurnal Rekayasa Informasi, Vol. 7, No.1, ISSN 2252-7354, 1322.

Kristian Reza Destiawan1), M. Z. (2018). Sistem Informasi Perpustakaan Ruang Publik Terpadu Ramah Anak Berbasis Web. Jurnal sains dan teknologi ISSN 2356 - 4393, 84-95.

Rahayu, I. D. (2016). Sistem Informasi Perpustakaan Berbasis Web Di Balai Pengkajian dan Pengembangan Komunikasi Dan Informatika Surabaya. Jurnal Kominukasi, Media Dan Informatika VoL 5 NO3, 143 - 152.

Wahyu Hidayat Ibrahim, 2. M. (2017). SISTEM INFORMASI PELAYANAN PUBLIK BERBASIS WEB PADADINAS PEKERJAAN UMUM KABUPATEN KAMPAR. Jurnal IImiah Rekayasa dan Manajemen Sistem Informasi, Vol. 3, No. 2, 17-22.

Yusri. (2015). SISTEM INFORMASI PERPUSTAKAAN BERBASIS WEB PADA SMP FRATER MAKASSAR . YUsri /JUPITER Vol. XIV No.2, 66-78.

E. Budiarti, "Sistem Informasi Pada Perpustakaan," 27 Maret 2014 [Online]. Available: https://erlisbudiarti.wordpress.com/2014/03/27/537/co mment-page-1. [Accessed 14 Januari 2017].

Anhar, Panduan Menguasai PHPdan MySQL secara otodidak, Jakarta: Media Kita, 2010, h/m. 21

Kadir, Abdul. 2003. "Dasar Pemograman Web Dinamis Menggunakan PHP". Andi Offset. Yogyakarta.

Y. Kustiyahningsih \& D. R. Anamisa, Pemrograman Basis Data Berbasis Web Menggunakan PHP \& MySQL, Yogyakarta: Graha IImu, 2011, hIm. 4.

Sulastri. (2013). Pembangunan Sistem Informasi Perpustakaan Pada Sekolah Menengah Pertama (SMP) Negeri 4 Karangtengah, Speed Journal Indonesian Jurnal on Computer Science-Vol 10 No 2 - Mei 2013, ISSN 1979 - 9330, Sulastri Bambang Eka Purnama Sukadi, Pembangunan Sistem Informasi Perpustakaan Pada Sekolah Menegah Pertama (SMP) Negeri 4 Karang Tengah. Speed Web - Volume 9 Nomor 2- 2012 ISSN : 1979-9330. 
Arip Aryanto' Berliana Kusuma RiastST.M.Eng², Pembuatan Sistem Informasi Perpustakaan Smp Muhammadiyah 7 Surakarta. Speed Web-Volume 2 Nomor 2 - 2012 ISSN : 9772088015. Hal 1-8.

Suwarno, Wiji, Dasar-Dasar Ilmu Perpustakaan Sebuah Pendekatan Praktis ArRuzz Sitorus, L. (2015). Algoritma Dan Pemrograman (1st ed.). Yogyakarta 